\title{
An Appraisal of Linguistic Capital Behavior Among Acehnese EFL Learners
}

\author{
Nyak Mutia Ismail, Iskandar Abdul Samad, and Siti Sarah Fitriani \\ English Department \\ Syiah Kuala university \\ Banda Aceh, Indonesia \\ nyakmutiaismail2010@gmail.com
}

\begin{abstract}
Nowadays, the power of English has changed people's perspectives toward their own native languages. Those who could speak English are recognized as knowledgeable persons. Nonetheless, traditional languages, Acehnese, should not be ignored, but it is preserved to avoid it from extinction. Literature has reported that most traditional languages in Aceh are in the phase of extinction. Acehnese teenagers seem reluctant to use Acehnese in their conversation. This is qualitative case study investigating the behavioral judgement of Acehnese people toward English and Acehnese language in coastal area of Aceh. A set of character-rubric in the Likert Scale was given to 207 Acehnese people, aged between 18 and 30, involved as respondents. The result shows that majority of the respondents felt more secure and comfortable with the Acehnese rather than the English ones. Acehnese is highly addressed in sense of humor, kindness, sociability, and religiousness. Meanwhile, English is highly used in the sense of ambition, leadership, intelligence, and confidence. This implies that Acehnese language in the coastal area could be sustained for a certain length of time in the future.
\end{abstract}

Keywords-foreign language, traditional language, linguistic capital, language attitude, foreign language learners.

\section{INTRODUCTION}

In many countries, people who could speak English is always an attention. At least, two factors pinpointing this fact. Firstly, looking back to its history, English is an IndoEuropean language which was firstly used in the 5th century A.D during the Anglo-Saxon's settlement in Britain. It has changed a lot of complex forms until English we know today, beginning with old English, middle English, pre-modern and modern English, and variety of Englishes as worldwide use today [1]. In addition, United Kingdom has been a highlylegitimated kingdom. Now, there are 52 countries across the world are gathered in its commonwealth [21].

As more and more people had grown up and urbanized in Britain, they needed another land so they migrated to Australia in the late 17th century [2]. These strong-determined people to cross the Pacific ocean and fought the Aboriginal Australian and they prevailed most of the land convictions in the continent. Shortly, as the English people started migrating from England since1600s, so we know it today 'English'.
Secondly, most of English speaking countries have the status of the super power countries - not much surprising if we look at the preserverance of their ancestors. Not only do they excel in military, political, and educational systems but also to the issues of fashion, music, food, and other entertainment trends. These countries have become the vocal front for other countries in the world in all life domains, including their language-English. Finally, it is the factor of globalization that has forced everyone to master English through the standardized testing system [6]—-such as TOEFL, IELTS, TOEIC, SAT, etc, international public service which are prone to employ English, and the most unavoidable one: technologies.

Indeed, modern life opens up to globalization and, to some extends, it does have good effects for people, especially Acehnese. Globalization has brought Acehnese to the magnificent level of civilization such as technology usage ability, wider access to study abroad, and opportunity to expand their career(s). Aceh is a province in most western part of Indonesia, and Banda Aceh is its capital. Back in the 17th century, Aceh was once a prosperous kingdom, too, and the language that Acehnese use today are presumed from the Malay-Polynesians heritage [20]. The number of Acehnese speakers is 3 millions [16] and it is declared as the most existential traditional language in Indonesia. 11 out of 13 traditional languages have been even closer to extinction with less than 50.000 native speakers. As a matter of fact, most parents - especially young ones with higher social statusfocusing their children to be able to speak excellent English. They think that English is a prestigious language. In addition, the use Bahasa Indonesia is more common rather than Acehnese in daily conversation. So, most Acehnese children may understand the Acehnese but they do not speak using the Acehnese in communication. We are questioning ourselves about the existence of this traditional language in the next few decades ahead.

Indeed, English plays a role as a foreign language but its power has overridden Acehnese perceptions on its use, permeating their linguistic capital. Linguistic capital is a subsection of cultural capital-knowledge, skills, and other cultural acquisitions obtained from educational and technical qualification [5]. It is a language chosen to use because of its legitimate prestige compared to other languages in a certain 
region [4]. It depends heavily on the surrounding atmospheres where people need to be seen as a legitimate person.

In Banda Aceh, it is found that the use of Acehnese by the youth is decreasing since most parents seem avoiding communicating using this language with their children. Consequenlty, The children do not often use this in their daily conversation either in cafes, restaurants, and schools. They prone to using some borrowing words or expressions from English rather than using Acehnese; or instead, they use Indonesian. For example, they decide to say "Thank you", "Sorry", "It's worth a try", "I don't know", "Let's do it", "Why not?", etc, instead of Acehnese expressions. It is so much likely that the cultural values have also shifted since the use of English expressions can heighten their power over people around them which refers to symbolic power [7, 5].

Concerning to this issue, researchers have discussed about language attitude. Before 1960s, discussions about language attitudes were not seen as an important part of language studies since they are considered as racist. However, Lambert et al [12] started to study the language attitudes of a group that used both English and French and, apparently, they shifted attitudes over these languages. Shorlty, an investigation of language attitude is no longer believed as a discriminative study but as psychologically mental activities of language [17]. Language attitudes are feeling a person has toward a variety(s) of their own language and that of other languagers. A person may have either positive and negative attitudes toward a certain language, however, there are also some people who justify neutral attitudes. Some factors are known to influence one's language attitude, they are: the prestige and power of a language, historical bacgkround of a country, social and traditional considerations, and the language internal system which means people tend to have more positive attitude toward easier-to-learn languages.

The authors are interested in looking the behavioral reactions of Acehnese people once they are exposed to English and Acehnese. The research question is: To what language does the Acehnese linguistic capital behavior incline? Is it English or Acehnese? And what are the implications?

\section{METHOD}

This is qualitative case study investigating the Acehnese linguistic capital behaviour. The instrument employed during the data collection was match-guised test as suggested by Lambert [14], which consist of two elements: (1). Recorded Acehnese voices speaking in Acehnese (Group A), and (2). Recorded Acehnese voices (the same persons) speaking in English (Group B). Questionnaires that the respondents have to fill in after they listen to the recordings. There were 4 native Acehnese - two of whom are men and the other two are women - spoke Acehnese and were recorded for 2 minutes; then again, they spoke English for two minutes with the same passage and were also recorded.

The recordings are monologues which means they were recorded individually and anonym to the respondents. Later, the respondents were asked to listen to these recordings and answer the questionnaire asking them to make predictions about the person they heard on the recording concerning to height, good-looking-ness, leadership, sense of humor, intelligence, religiousness, self-confidence, dependability, kindness, ambition, socialibity, character, and likability [19]. Simply, it is about their impression and label they give on the language user. Questionnaires are self-report data sources that can effectively be used to know what in individual have in mind and feel toward a particular issue [9].

There were 207 native Acehnese involved in this study within December 2016 and February 2017. These respondents vary in age-between 18-30 years old; occupation-university students, traders, civilian officers, and housewives; education level-high-school graduate, bachelor, and master; and none of them has been to the Englishspeaking countries. As soon as the data were obtained, they were analyzed through data reduction, data display,a nd data verification [15].

\section{FINDING AND DISCUSSION}

Below is the result of Acehnese people attitude toward English and Acehnese. Thirteen categories have been displayed to see their language attitude. The detail can be seen in the following chart.

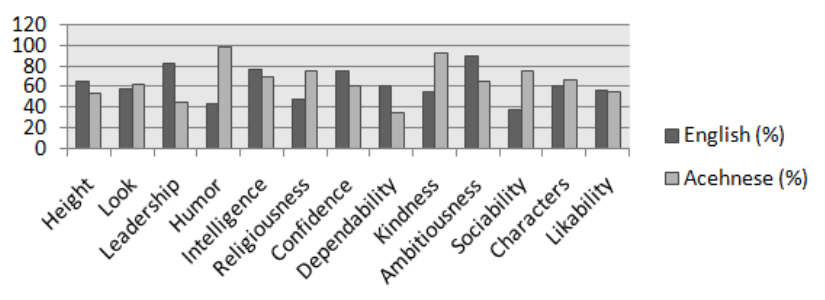

Fig. 1. Acehnese people's Perception toward English and Acehnese

In the Figure 1 above, it can be seen that the highest peak is represented in Humor and Kindess by Acehnese, respectively. Then it is followed by Religiousness and Sociability. Meanwhile, for English, the highest peak is shown is Ambitiosness, leadership, intelligence, and confidence. Later, we can also learn that in Height, an Acehnese who speaks English is higher than an Acehnese who speaks Acehnese. Then in Look, the one who speaks Acehnese looks slightly better; in Leadership, English is considered more fluctuative than Acehnese; in sense of humor, Acehnese people are better; while in intelligence, there is almost similar claim between English and Acehnese. Next, in Religiousness, Acehnese percentage inclines as formerly mentioned; both in Confidence and Dependability, English is seen as more dependable unless it comes to kindnes, sociability, and characters. Lastly, in Likability, the perception is nearly tied for both languages.

Generally, it can be seen that in both languages, Acehnese have almost similar perceptions. There is no outlier points which are extremely low from the mean score. This implies that Acehnese peole have more secure attitude toward Acehnese in term of humor, kindness, sociability, amd 
religiousity. In respect to both languages, these are considered as vernacular attitudes - which are more natural and colloquial to the language users. Meanwhile English is seen as more prestigious due to its profesionally-contextualized atmospheres (ambition, leadership, intelligence, and confidence) in which Acehnese feel less secure and comfortable. This is supported by Lambert et al [13] and Ladegaard [11] in more positive attitudes are present in colloquial condition and with in-group members. For instance, when a teenager is hanging out at a restaurant with some friends who are considered more classy, he/she tends to use Indonesian-with some English phrases and expressions rather than Acehnese ones; contrarily, when communicating with family members or closer friends, they entirely use Acehnese (unless their parents or friends do not). These diglossic conditions show that he/she tries to earn more prestige in a more "standard" condition. especially for women who are more insecure and show more negative attitudes toward vernacular conditions [10]. This clarifies the fact that women are more sensitive to prestige compared to men.

Then, in the following graph is presented the holistic percentage of both English and Acehnese language.

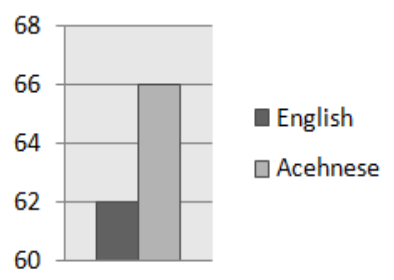

Fig. 2. Language Attitude toward English and Acehnese

Figure 2 above shows that there is basically a slight difference between Acehnese perceptions toward an Acehnese who speaks English and the one who speaks Acehnese. The difference is only shown in $4 \%$. However, there is a higher percentage between these languages; the attitude propensity is in Acehnese.

Weighing up both sides of arguments, contributions to both languages are worth to address. The merits are solely on the field of English language teaching. First, students' motivation in learning English are certainly high nowadays and beyond their needs to mark on verbal behaviors, they also adopt characters of other language groups [14]; and second, there is a possibility in a few decades ahead to merge English as the second language in Aceh and bring Aceh to globallyaccessed province in terms of knowledge and business worldwide as it is believed the more language acquired, the more worthy a person is [8]. Nevertheless, there are also the negative possibilities promoted in this situation. Initially, Acehnese people are going to use less Acehnese, for certain. And this is what comes as a fear of losing another traditional language. Next, since more middle-class (or higher) people will use English, the ones who insist on using Acehnese would be acknowledged as low-level classes and less educated. This could extensify self-hate of the minority since by then English usage is seen as a mark of success $[18,3]$.
Taken as a juxtaposition, although the percentage of Acehnese perception on English and Acehnese language is slightly different, there is indeed a difference. the $4 \%$ shows that Acehnese are still prone to feel more secure and comfortable in their traditional language which serves more vernacularity and non-standard conditions. This is said so because their comfortable feelings are based on the same solidarity shared when two Acehnese peole, for example, are speaking Acehnese rather than when two Acehnese people are speaking English language. They get more distant, but more distiguished, when speaking a language instead of Acehnese.

\section{CONCLUSION AND RECOMMENDATION}

Although Acehnese people have seen English as part of their linguistic lives both in academic and technical conditions and are using less Acehnese language everyday, they still feel more comfortable and secure with their traditional language, Acehnese. Therefore, the Acehnese language capital is inclined. People are concerned about the extinction of this language.

\section{References}

[1] Algeo, J. "The origin and development of the English language". Boston: Wadsworth. 2015.

[2] Ballyn, S. The British invasion of Australia in Lives in Migration: Rupture and Continuity. In Renes, M. (ed), An introduction to lives in migration: rupture and continuity. Australian Studies Center. 2011. Retrieved from://http: www.ub.edu/dpfilsa/2ballyn.pdf

[3] Baratz, J. C. "Educational consideration for teaching standard English to Negro children". In Fasold, R. W ans Shuy, R. W. (eds), Teaching standard English in the inner city. Center for Applied Linguistics, Washington. 1970.

[4] Bourdieu, P. "The economics of linguistic exchanges". Social Science Information, 16.1 1977: 645-668.

[5] Bourdieu, P. “Language and symbolic power”. Cornwall: T. J Press Ltd. 1991.

[6] Brown, H.D. "Language Assessment: Principles and Classroom Practices" New York: Longman. 2004.

[7] Collins, J. "The culture wars and shifts in linguistic capital: for combining political economy and cultural analysis". International Journal of Qualitative Studies in Education, 12.3 1999: 269-286.

[8] Friedman, V. A. "Languages are wealth: the Sprachbund as linguistic capital". In the proceedings of the 32nd annual meeting of the Berkeley Linguistic Society, 2012: 163-177.

[9] Holmes, J. "Language attitude studies: potential uses in New Zealand". Kivung, 2 1973: 131-146.

[10] Labov, W. "The social stratification of English in New York City". Center for Applied Linguistics, Washington. 1966.

[11] Ladegaard, H. J. "Language studies and sociolinguistic behaviour: exploring attitude-behaviour relations in language". Journal of Sociolinguistics, 4.2 2000: 214-233.

[12] Lambert, W. E., Hodgson,R. C., Garder, R. C., and Fillenbaum, S. "Evaluational reaction to spoken language". Journal of Abnormal and Social Psychology, 60 1960: 44-51.

[13] Lambert, W. E., Garder, R. C., Olton, R., and Tunstall, K. “A study of the roles of attitudes and motivation in second language learning". Mimeo: McGill University. 1962.

[14] Lambert, W.E. “A social psychology of bilingualism”. Journal of Social Issues, 23.2 1967: 91-109. 
[15] Miles, M. B., Huberman, A. M., \& Saldana, J. "Qualitative data analysis”. London: SAGE publications. 2013.

[16] Pusat Penelitian Kependudukan. "Ancaman kepunahan merebak masif". 2016. Retrieved from://http: www.kependudukan.lipi.go.id/id/berita

[17] Schiffman, L. G., and Kanuk, L. L. "Consumer behaviour". Upper Saddle River, N.J: Prentice Hall. 1997.

[18] Shuy, R. W., Baratz, J. C., and Wolfram, W. A. "Sociolinguistics factors in speech identification". 1969. Final report, MH 15048-01. National Institute of Mental Health Research.
[19] Stefanowitsch, A "The function of metaphor: developing a corpus-based perspective". International Journal of Corpus Linguistics, 10.2 2005: 161-198.

[20] Sulaiman, B. "Bahasa Aceh". Darussalam, Syiah Kuala University Press. 1977.

[21] The Commonwealth. Member countries. 2017. Retrieved from:/http www.thecommonwealth.org/member-countries. 